\title{
Metzingera „Duchowość a uczciwość intelektualna”. Komentarz
}

\author{
Łukasz Jędrzejczak \\ Instytut Filozofii \\ Uniwersytet Warmińsko-Mazurski w Olsztynie \\ syd[]indelia.org \\ Przyjęto: maj 2014; zaakceptowano: czerwiec 2014; opublikowano: lato 2014.
}

\begin{abstract}
Abstrakt
Autor komentuje esej Thomasa Metzingera „Duchowość a uczciwość intelektualna”, dokonując próby wyciągnięcia dalszych konsekwencji z poglądów niemieckiego filozofa.
\end{abstract}

Słowa kluczowe: duchowość; mistyka; religia; dysonans poznawczy; racjonalizacja; medytacja; racjonalizm.

W 2007 roku, w sali wykładowej Katolickiego Uniwersytetu w Lublinie po projekcji filmu o mózgu Alberta Einsteina, który był emitowany w ramach Dni Mózgu, jeden z obecnych na sali studentów wstał i - wskazując ręką na zdjęcia organu - krzyknął w stronę profesora Włodzisława Ducha, znajdującego się na widowni: „I czy pan uważa, że to jest rzeczywiście pan?!”. Profesor Duch miał wcześniej wykład pod tytułem „Czy jesteśmy automatami? Wolna wola, podmiotowość i mózg”, a to dywergencyjne pytanie zostało bez odpowiedzi, ponieważ uniesiony student od razu wybiegł z sali.

Nie trzeba dużo naukowej odwagi, by powiedzieć, że racjonalizacja dysonansu poznawczego to najważniejsza cecha homo sapiens, która utrzymuje ten gatunek przy życiu. Nie skaczemy z okien z różnych powodów, których nierespektowanie mogłoby przecież skutecznie pozbawić życie sensu. Większość ludzi nie mieszka $\mathrm{w}$ willach, nie posiada samochodu z plakatów, narratorem dnia nie jest Ian Fleming, a noc to nie zawsze film erotyczny. Największy jednak dysonans powoduje własna śmiertelność, którą na dodatek poprzedzają niezbyt lubiane efekty starzenia. 
W swoim eseju Thomas Metzinger (2013) skupia się na największym z procesów racjonalizacji dysonansu poznawczego człowieka. Proces ten zaczął się na samym początku istnienia gatunku ludzkiego i z pewnością nie był to pomysł jednego osobnika ani generacji. Natomiast jego rezultat filozof ten nazywa adaptacyjnym systemem urojeniowym, czyli lekką chorobą psychiczną (urojeniową), która - wprowadzona do umysłu - działa jak lekarstwo. Nie jest to nic innego niż panaceum na prawdę. W tym kontekście można powiedzieć, że początek wierzeń religijnych to początek jednej z najważniejszych umiejętności naszego gatunku: oszukiwania samego siebie oraz wzajemne wspieranie się w tym. Co prawda, inne gatunki potrafią świetnie fałszować rzeczywistość w celach adaptacyjnych, ale to człowiek na drodze ewolucji mózgu i pojmowania swojej sytuacji musiał stworzyć samooszustwo, by żyć i by na życiu mu zależało. Będąc konsekwentnym ewolucjonistą, można dodać, że skoro zmiany te zaszły $\mathrm{w}$ organizmach posiadających DNA, to nowa cecha podlega wszystkim prawom ewolucji. Zjawisko to prezentuje się interesująco w świetle hipotezy memów (Dawkins 1976/1996). Mamy zatem zespół mutacji, które tworzą pewne cechy organizmu, pomagające mu osiągnąć lepszy wynik reprodukcyjny ${ }^{65}$. Zespół tych cech jest zdolnością do tworzenia memów ${ }^{66}$, które na zasadzie sprzężenia zwrotnego działają terapeutycznie na organizmy będące nosicielami adaptującego się w ten sposób DNA. Tu można wykonać paralelę do rozróżnienia, którym zajmuje się Metzinger, czyli na religię i duchowość.

Autor eseju „Duchowość a uczciwość intelektualna” wyraźnie rozdziela duchowość i religijność. Intencje wydają się zrozumiałe, a praca w tym kierunku nie jest jakimś novum, lecz niemiecki filozof wręcz antagonizuje te dwa pojęcia. Metzinger słusznie uwypukla elementy dogmatyczne i fideistyczne w religii. Trudno też się z nim spierać poprzez utrzymywanie, jakoby człowiek religijny był wolny podczas podejmowania decyzji na poziomie swojej moralności lub orzekania o naturze świata, granicach ostatecznych czy prawdzie przez wielkie „P” - a to, w gruncie rzeczy, jest przecież pracą naukowca. Dychotomia duchowość-religia wydaje się adekwatna do rozróżnienia mistykateologia. Taki podział przynosi wymierne korzyści przy naukowych rozważa-

\footnotetext{
${ }^{65}$ Nie jest to miejsce na udowodnianie tezy, iż religia jest wytworem ewolucji. Na tym etapie polemiki przyjmuję to po prostu za pewnik. Dla przeciwników tej tezy wspomnę tylko, że refutacja takiej teorii nie polega na udowodnieniu niemożliwości wskazania na konkretny „gen religijności”. Religijność jest zbiorem ogromnej liczby cech gatunku, a dodać należy, że część z nich posiadają już inne ssaki (jak np. posłuszność i bezkrytyczność w wieku dorastania względem wiedzy rodziców).

${ }^{66}$ Aktualnie pojęcie memu sprawdza się chyba najlepiej do potrzeby opisania walki idei w dyskursie, który byłby akceptowalny dla psychologów ewolucyjnych, biologów i kognitywistów. Interesujące byłoby również posługiwanie się pojęciem „koalicji neuronalnych” (Koch 2004/2008), lecz w kontekście prac Kocha wydaje się to zbyt związane z pojęciem świadomości „tu i teraz”.
} 
niach tego typu ${ }^{67}$. Mistyka i duchowość nie są tym samym co religia i koncepcje teologiczne. Tak zwane zachowania duchowo-mistyczne są bardziej intymne i nie tak normatywne jak w przypadku zinstytucjonalizowanej religii. W celach naukowych wprowadzenie takiej dychotomii bardzo pomaga, ponieważ mistykę czy duchowość przypisuje się predyspozycjom genetycznym człowieka, natomiast religia jest już bardziej wyszukaną formą kulturową i zależy od geograficznych ognisk powstania danej kultury. Metzinger słusznie wskazuje na pewną opresyjność religii wobec duchowości mistycznej. W momencie instytucjonalizowania się duchowości powstaje religia, a wraz z nią kontrolowanie mistyczności przez poziom memowy. Wspomagając podejście Metzingera, można zadać pytanie, dlaczego tak się dzieje; dlaczego mistyka nie może zostać wolna? Odpowiedź wydaje się dość prosta, a całość można by sprowadzić do wojny memów. Zespoły memów religii, czyli najlepsze lekarstwo na największy ludzki dysonans, były dobrze chronione, a koalicje memów tego typu miały wysoką pozycję wśród innych koalicji memowych. Mistyk, czyli potencjalny rewolucjonista, generujący zdania o znaczniku bliskim memom religii, był poważnym zagrożeniem, które wchodziło na teren dobrze już ugruntowanych i działających urojeń adaptacyjnych. Jeśli duchowo natchniona jednostka pragnęła się wypowiedzieć, to lepiej żeby to wspierało struktury zastanego $\mathrm{w}$ danym społeczeństwie lekarstwa na wspomniany hiperdysonans. Na burzących świętą idyllę były różne metody perswazji, że wymienię tutaj tylko chrześcijańskie stosy czy muzułmańskie kamieniowanie heretyków.

Jako że memy panoszą się w ludzkich mózgach niczym wirusy, i tutaj było podobnie $^{68}$. Ale przecież religia to nie samo słowo; nie jakiś pojedynczy mem w postaci jednego aksjomatu czarującego rzeczywistość. Idee religijne nadały postać innym zbiorom memów, tworząc je również niebezpiecznymi dla nazwijmy to za Metzingerem - bezwarunkowym pragnieniem wiedzy, a dalej - cnoty intelektualnej. Daniel Dennett (2006/2008) do takich niebezpiecznych memicznych idei zalicza nie tylko religie, ale i idee sprawiedliwości, prawdy, a nawet wolności. Są to idee, za które „warto” umierać, ponieważ zajęły tak ważne miejsca w naszych mózgach i tak bardzo są nam pomocne w radzeniu sobie z rzeczywistością.

Dlaczego takie wzmocnienie zdania Metzingera na temat religii zostało wyartykułowane w niniejszej refleksji nad jego esejem o uczciwości intelektualnej? Po pierwsze, by wyrazić aprobatę wobec jego opinii, iż system fideistycznodogmatyczny, jakim jest zinstytucjonalizowana religia, rzeczywiście ma silny

\footnotetext{
${ }^{67}$ Poszukując neuronalnych korelatów świadomości, doznanie mistyczne jest dziś łatwiejsze do zbadania metodami neurokognitywistycznymi niż bardziej złożony memowy system teologicznoreligijny. Efekty takich prób można już oceniać od kilku lat (zob. Jędrzejczak 2010).

${ }^{68}$ Szczególnie, że ferment taki żyzny, ponieważ któż nie chciałby żyć wiecznie?
} 
i rozległy wpływ na indywidualne światopoglądy, co można tłumaczyć również $\mathrm{w}$ dyskursie ewolucjonistycznym. Po drugie, aby posunąć się dalej niż Metzinger i zrobić wstęp do pewnego zradykalizowania jego myśli tam, gdzie on sam nieco łagodzi swoją hardość, włączając w zakres istotnych metod poznawczych formę, na którą nie każdy naukowiec może przystać.

Metzinger pisze, iż uczciwość intelektualna to - w najprostszych słowach niebycie skłonnym do oszukiwania samego siebie. Rzeczywiście, nie jest to proste, kiedy całe nasze życie można tłumaczyć racjonalizacjami dysonansów poznawczych. Człowiek niemal bez przerwy redukuje nieprzyjemne napięcia różnymi formami racjonalizacji swoich wyborów (szczególnie tych trudnych do odwrócenia), ciężkiej pracy czy wręcz jej niewykonywania. Racjonalizujemy za każdym razem, gdy wypowiadamy się tak lub podobnie: „i tak bym się spóźnił”, „za to cena była niska”, „może następnym razem”, „tak widocznie musiało być”, „będzie się smażył w piekle”, „ma natomiast świetne poczucie humoru”, ,i tak nie był mnie wart” i tak dalej, ad infinitum. Z jakiego typu racjonalizacją mamy do czynienia w miarę zbliżania się do końca lektury eseju Metzingera? Po pierwsze wydaje się ona racjonalizacją zasmakowanej formy poznania medytacyjnego, która całkiem dobrze pokrywa się z wnioskami filozoficznymi tego naukowca na temat złudzenia ego/ja. Po drugie można wyczuć zawód nad niesatysfakcjonującymi odpowiedziami na ważne tematy, których nie może obecnie udzielić nauka (co uważam za częstą przyczynę zejścia naukowców do świata paranauki lub dosadniej - bajkopisarstwa). Chodzi zatem o usprawiedliwianie drogi, która przynajmniej da złudzenie wiedzy. Chodzi tu o nobilitację duchowej metody poznania, którą ma być choć nie czytamy tego wprost - medytacja lub jakaś inna forma wprowadzenia się w stan odmiennej świadomości. Interpretacja taka może się wydać na wyrost, ale takie wrażenie odnoszę po przeczytaniu omawianego tekstu niemieckiego filozofa, mimo że kilka stron wcześniej ostrożniej traktuje on o duchowości naukowca, którą na przykład cechować powinny „powaga i szczerość (...), radykalne otwarcie na krytycyzm i ścisłe opieranie się na doświadczeniu w poszukiwaniu formalnej elegancji i prostoty" (2014: 395) ${ }^{69}$. Metzinger najwyraźniej chciałby powiedzieć coś, „o czym należy milczeć” (Wittgenstein 1921/2006: T.7), ale doskonale zdaje sobie sprawę, że droga ta nie wiedzie przez metodykę obowiązującą w świecie restrykcyjnej nauki. Argumentowi za tym, że wiele szanowanych postaci z kręgu nauki było według Metzingera uduchowionych (tutaj: Popper, Sokrates) można z łatwością przeciwsta-

\footnotetext{
${ }^{69}$ Zauważmy przy okazji, że naukowiec nie ma innego wyjścia niż poddać się krytyce. Natomiast „doświadczenie” w tej wypowiedzi Metzingera można odebrać dwojako: empirystycznie oraz osobiście. W tym drugim kontekście na myśl przychodzi doświadczenie pierwszoosobowe, lecz ono jest tylko o tyle warte, o ile trzymamy się zasad heterofenomenologicznych (Dennett 1992, 2005/2007), te natomiast każą nam podejść do raportów introspekcyjnych trzecioosobowo. Przy kierowaniu się w stronę empirii w takim wydaniu nie będzie nigdy orzekało „osobiste doświadczenie naukowca”, tylko „wszechwiedzący narrator” (2005/2007).
} 
wić kontrargument, że wiele postaci filozofii, również uduchowionych, okryło się gorszą sławą lub że wiele osób, mimo że ważnych dla nauki, trudno uznać za uduchowione.

Mimo że większość pracy wykonanej przez autora jest pożyteczna, to dopuszczenie formy poznania innej niż racjonalna - nawet jeśli nieznacznie - może wywołać silne odczucia ambiwalentne. Jako eseista, Metzinger trafnie eksponuje ideał uczciwości intelektualnej, ale ten sam ideał nie pozwala racjonalnemu umysłowi zgodzić się na podział poznania na wschodnie i zachodnie, duchowe i racjonalne, oświecone i wyprowadzone na drodze wnioskowania logicznego. Więcej: racjonalność nie pozwala nawet na poznanie ludzkie. Ideał racjonalności wykracza daleko poza ułomności człowieka, nigdy się z nimi nie godząc (jak chciałby autor eseju), nawet jeśli jest to skazane na porażkę. Osoba oświecona będzie twierdzić, że posiada „wgląd”, że „wie”, nawet jeśli wie tylko tyle, że nie wie. Wgląd taki daje pewien spokój i spełnienie, ale to tylko kolejna forma radzenia sobie $\mathrm{z}$ dysonansem poznawczym, który powoduje tutaj świadomość, że poznanie naukowe to proces nieskończony przy naszej ludzkiej skończoności. Jest to kolejne samooszustwo, które ma zastąpić ów dysonans wynikający ze zdania sobie sprawy z ułomności poznania ludzkiego. Zwykłe przejście na następny metapoziom oszukiwania samego siebie. Czy tak musi być? Czy jesteśmy skazani na pokonywanie kolejnych metapoziomów tylko na swojej ludzkiej płaszczyźnie epistemicznej? Z dwóch powodów - nie. Po pierwsze jesteśmy namacalnym kodem genetycznym, obudowanym w ciało, które będzie ewoluować w stronę formy stale zwiększającej swoje zdolności epistemiczne (zmiany te jednak stają się już dla nas za wolne, z nich wynika opisany wyżej zawód myśli ludzkiej nad własnymi zdolnościami poznawczymi). Po drugie prace na polu neuronauk, których entuzjastą jest również Metzinger, prowadzą do uwolnienia się od ułomności mechanizmów ewolucyjnych cechujących każdego posiadacza kodu DNA. Pozbywając się kilkumilionoletniego kodu genetycznego, być może nie nazwiemy już siebie istotami żywymi, ale z pewnością - bardziej wolnymi niż w tej chwili. Wolność taką na pewno poparłby i sam Metzinger; jednak na drodze medytacji, z jej częstym nastawieniem się na wstrzymanie od działania i leniwe dystansowanie się od poznania naukowego, tego nie osiągniemy. W chwili obecnej lepszą propozycją nadal zostaje racjonalne przekonywanie, a nie piękne oświecanie (czy to prawdami o świecie, czy bardziej naukowo: wiedzą, o tym, jak działa świat).

Na koniec chciałbym jeszcze wspomnieć o pewnej luce, którą - jak mniemam - starał się wypełnić Thomas Metzinger. Chodzi o ewolucyjnie wykształconą zdolność do doznania mistycznego, duchowego czy oświeceniowego, która bez religii miałaby przybrać postać zsekularyzowaną, a o którą wydaje się nie dbać nauka i naukowość. Zdolność do „duchowości” wydaje się najwyraźniej pozostałością ewolucyjną, taką jak na przykład kość ogonowa. Jest to pewien atawizm, ale dopóki nas cechuje, będziemy go uważać za piękny. I słusznie, 
ponieważ taki jest (w końcu autor tego tekstu jest również człowiekiem). Nie omawiając już każdej z nich, wymienię drogi, które moim zdaniem z powodzeniem mogą prowadzić do zaspokojenia potrzeby duchowości przy silnym powiązaniu z konsekwentnym poznaniem racjonalnym. Takimi gloryfikowanymi elementami naszego podejścia do życia mogą być: ciekawość, wątpienie oraz doskonalenie rezultatów, a także ona sama - metoda naukowa, którą tutaj uznaję za najlepsze narzędzie na drodze ku wolności świadomości.

\title{
Literatura
}

Dawkins, R. 1976/1996. Samolubny gen. Przeł. M. Skoneczny. Warszawa: Prószyński i Ska.

Dennett, D.C. 1992. Consciousness Explained. Boston: Back Bay Books.

Dennett, D.C. 2005/2007. Stodkie sny. Filozoficzne przeszkody na drodze do nauki o świadomości. Przeł. M. Miłkowski. Warszawa: Prószyński i S-ka.

Dennett, D. 2006/2008. Odczarowanie. Religia jako zjawisko naturalne. Przeł. B. Stanosz. Warszawa: Państwowy Instytut Wydawniczy.

Jędrzejczak, Ł. 2010. O powstawaniu doznań mistycznych. Podejście neurokognitywne. Olsztyn: Wydawnictwo Instytut Filozofii UWM.

Koch, C. 2004/2008. Neurobiologia na tropie świadomości. Przeł. G. Hess. Warszawa: Wydawnictwo Uniwersytetu Warszawskiego.

Metzinger, T. 2013. Duchowość a uczciwość intelektualna. Przeł. P. Nowakowski. Avant, IV, 2/2013: 368-402.

Wittgenstein, L. 1921/2006. Traktat logiczno-filozoficzny. Przeł. B. Wolniewicz. Wydawnictwo Naukowe PWN: Teza 7.

\begin{abstract}
The author comments on the essay "Spirituality and Intellectual Honesty" by Thomas Metzinger. He attempts to draw further conclusions from the Philosopher's account.

Keywords: spirituality; mysticism; religion; cognitive dissonance; rationalization; meditation; rationalism.
\end{abstract}

